\title{
PENGEMBANGAN BAHAN AJAR MATEMATIKA DENGAN MODEL DISCOVERY LEARNING UNTUK MENGEMBANGKAN KETERAMPILAN BERPIKIR KRITIS
}

\author{
Deni Efendi ${ }^{1}$ \\ ${ }^{1}$ Program Studi Pendidikan Matematika Universitas Muhammadiyah Lampung \\ email: deni04@gmail.com
}

\begin{abstract}
This research aimed to find out the validity and effectivity of Discovery Learning Model-integrated mathematics instructional materials on SPLDV topic viewed through critical thinking skill improvement and percentage of students' learning completion. It occupied Reserach and Development utilizing procedures established by Borg and Gall, with only performing up to main product revision. The research subject was students VIII G class of SMP Negeri 1 Seputih Agung, with moderate to high skill characteristic. Meanwhile, data of students' critical thinking skill improvement were gained through pretest and posttest, using $N$-Gain test. Eventually, the research result pointed out that validation of mathematics instructional materials developed through Discovery Learning Model on SPLDV topic attained good and effective interpretation. It was seen through moderatecategorized calculation of $\mathrm{N}$-Gain and accomplishment level of students' learning result exceeding ideal accomplishment percentage (75\%).
\end{abstract}

Keyword: critical thinking, discovery learning, instructional materials

\section{PENDAHULUAN}

Keterampilan berpikir kritis merupakan keterampilan yang sangat penting untuk kehidupan sehingga tercantum dalam salah satu tujuan pelajaran matematika yaitu agar peserta didik memiliki keterampilan berpikir logis, analisis, sistematis, kritis dan kreatif (Depdiknas: 2006), namun beberapa penelitian menunjukkan bahwa keterampilan berpikir kritis peserta didik kelas VIII SMP di Indonesia masih rendah. Rendahnya kemampuan ini menggambarkan rendahnya kemampuan penalaran matematis peserta didik yang ditunjukan dengan ketidakmampuan peserta didik Indonesia dalam menjawab soal-soal matematika tidak rutin yang meliputi pengetahuan, aplikasi dan penalaran. Berdasarkan hasil pengamatan di SMP Negeri 1 Seputih Agung, didapati hasil nilai ulangan harian matematika pada bab Persamaan Linier Satu Variabel dengan ratarata nilai sebeser 68,9 . Peserta didik yang mendapatkan nilai melampaui KKM sebanyak 10 orang dari seluruhnya 32 orang. Hal tersebut sesuai dengan studi yang dilakukan oleh Trends in International Mathematics and Science Study (TIMSS) pada tahun 2011 bahwa kemampuan matematika peserta didik kelas VIII SMP di Indonesia 
berada pada peringkat ke 38 dari total 42 negara dengan skor 386 (Kemendikbud, 2012).

Salah satu upaya yang dilakukan untuk meningkatkan keterampilan berpikir kritis peserta didik yaitu melalui penerapan model-model pembelajaran. Salah satu model pembelajaran yang baru-baru ini digunakan dalam penerapan kurikulum 2013 dengan pendekatan saintifik adalah Discovery Learning. Budiningsih (Kemendikbud, 2014:30), menyatakan bahwa Discovery Learning merupakan model pembelajaran penemuan, yang peserta didiknya memahami sendiri konsep, arti, dan hubungan melalui proses intuitif untuk akhirnya sampai kepada kesimpulan. Dengan demikian, pembelajaran menggunakan pendekatan saintifik melalui model Discovery Learning akan mengembangkan keterampilan berpikir kritis peserta didik dalam pembelajaran, karena peserta didik menemukan sendiri suatu konsep melalui pengalaman ilmiah, mengonstruksi konsep, hukum atau prinsip.

Penerapan model Discovery Learning dalam kegiatan pembelajaran melibatkan langkah-langkah pembelajaran yang harus diikuti oleh peserta didik. Langkah langkah pembelajaran tersebut dapat disusun dalam bahan ajar yang nantinya dapat digunakan peserta didik dalam kegiatan pembelajaran. Bahan ajar merupakan salah satu komponen penting dalam pembelajaran yang mendukung peserta didik untuk mencapai standar kompetensi yang diinginkan. Bahan ajar yang disusun dengan model Discovery Learning akan menjadi bahan ajar yang berorientasi kepada peserta didik dan meningkatkan keterampilan berpikir kritis peserta didik karena terdapat langkah langkah Discovery Learning yang melibatkan peserta didik untuk aktif dalam pembelajaran.

Pembelajaran menjadi lebih bermakna ketika peserta didik mengeksplorasi lingkungan pembelajaran secara aktif dibandingkan secara pasif mendengarkan guru menerangkan (Schunk, 2012). Tujuan utama penggunaan Model Discovery Learning, yaitu menjadikan peserta didik berpikir untuk kebutuhannya, membantu peserta didik menemukan bagaimana suatu pengetahuan dapat dibentuk, dan mendukung keterampilan berpikir tingkat tinggi. Kriteria model Discovery Learning, yaitu guru mengatur pembelajaran agar tercipta suasana penemuan, guru mengajak peserta didik berpikir, peserta didik melakukan penyelidikan untuk penemuan, tingkat partisipasi dan interaksi peserta didik tinggi, serta peserta didik dapat mengoperasikan keterampilan berpikir tingkat tinggi yang diperoleh berupa kemampuan menganalisis, menyintesis, dan mengevaluasi (Cruickshank, 2006)

Penerapan model Discovery Learning dalam pembelajaran dapat dila- 
kukan dengan mengintegrasikannya dalam bahan ajar. Widodo dan Jasmadi (2008:40) mengatakan bahwa bahan ajar adalah seperangkat sarana atau alat pembelajaran yang berisikan materi pembelajaran, metode, batasan-batasan, dan cara mengevaluasi yang didesain secara sistematis dan menarik dalam rangka mencapai tujuan yang diharapkan, yaitu mencapai kompetensi atau subkompetensi dengan segala kompleksitasnya

Pengembangan bahan ajar hendaklah memerhatikan prinsip-prinsip dari pemilihan bahan ajar. Prinsip pengembangan bahan ajar menurut Amri dan Ahmadi, (2010: 160) sebagai berikut.

1. Mulai dari yang mudah untuk memahami yang sulit, dari yang konkret untuk memahami yang abstrak.

2. Pengulangan akan memperkuat pemahaman.

3. Umpan balik positif akan memberikan penguatan terhadap pemahaman peserta didik.

4. Motivasi belajar yang tinggi merupakan salah satu faktor penentu keberhasilan belajar.

5. Mencapai tujuan ibarat naik tangga, setahap demi setahap, akhirnya akan mencapai ketinggian tertentu. Mengetahui hasil yang telah dicapai akan mendorong peserta didik untuk terus mencapai tujuan.
Bahan ajar yang diintegrasikan dengan Model Discovery Learning diharapkan dapat mengembangkan keterampilan berpikir siswa. Kemampuan seseorang untuk dapat berhasil dalam kehidupannya antara lain ditentukan oleh keterampilan berpikirnya, terutama dalam hal menyelesaikan masalah-masalah kehidupan yang dihadapinya. Salah satu dari keterampilan berpikir yang harus kita miliki adalah keterampilan berpikir kritis. Menurut Lau \& Chan (Yunarti, 2009) berpikir kritis adalah keterampilan untuk berpikir secara jelas dan rasional. Berpikir kritis meliputi kemampuan untuk terlibat dalam berpikir reflektif dan independen. Seseorang yang memiliki keterampilan berpikir kritis akan siap untuk memahami hubungan logis antar ide, mengidentifikasi, mengkonstruksi, dan mengevaluasi perbedaan-perbedaan pendapat memecahkan masalah masalah secara sistematis. Selain itu, mengidentifikasi serta merefleksi ide ide yang relevan dan penting, serta merefleksikan kebenaran dari kepercayaan dan nilai nilai yang diyakini seseorang.

Facione (Kowiyah, 2012) juga membagi proses berpikir kritis menjadi enam kecakapan, yaitu interpretasi, analisis, evaluasi, inference, penjelasan dan regulasi diri.

1. Interpretasi, menginterpretasi adalah memahami dan mengekpresikan makna dari berbagai macam pengalaman, 
situasi, data, penilaian prosedur atau kriteria. Interpretasi mencakup subkecakapan mengkategorikan, menyampaikan signifikasi dan mengklarifikasi makna.

2. Analisis, menganalisis adalah mengidentifikasi hubungan inferensial dan aktual diantara pertanyaan-pertanyaan, konsep-konsep, deskripsi untuk mengekpresikan kepercayaan, penilaian dan pengalaman, alasan, informasi dan opini. Analisis meliputi pengujian data, pendeteksian argumen, menganalisis argumen sebagai subkecapakan dari analisis.

3. Evaluasi, berarti menaksir kredibilitas pernyataan-pernyataan atau representasi yang merupakan laporan atau deskripsi dari persepsi, pengalaman dan menaksir kekuatan logis dari hubungan inferensial, deskripsi atau bentuk representasi lainnya. Contoh evaluasi adalah membandingkan kekuatan dan kelemahan dari interpretasi alternatif.

4. Inference, berarti mengidentifikasi dan memperoleh unsur yang diperlukan untuk membuat kesimpulan-kesimpulan yang masuk akal, membuat dugaan dan hipotesis, mempertimbangkan informasi yang relevan dan menyimpulkan konsekuensi dari data.

5. Eksplanasi/Penjelasan, berarti mampu menyatakan hasil-hasil dari penalaran seseorang, menjustifikasi penalaran tersebut dari sisi konseptual, metodologis dan konstektual.

6. Regulasi Diri, berarti secara sadar diri memantau kegiatan-kegiatan kognitif yang telah dilakukan, unsur-unsur yang digunakan dalam hasil yang diperoleh, terutama dengan menerapkan kecakapan di dalam analisis dan evaluasi untuk penilaiannya sendiri.

Keterampilan berpikir kritis dapat dikembangkan melalui pembelajaran bermakna dengan menggunakan bahan ajar. Bahan yang dipelajari, yaitu berupa bahan ajar ma-tematika dengan Model Discovery Learning. Oleh sebab itu tujuan yang akan dicapai dalam pengembangan ini adalah mengembangkan bahan ajar matematika dengan Model Discovery Learning pada pokok bahasan SPLDV yang valid dan efektif dalam mengembangkan keterampilan berpikir kritis peserta didik.

\section{METODE PENELITIAN}

Penelitian ini adalah penelitian pengembangan yang mengacu pada metode penelitian dan pengembangan (Research \& Development). Penelitian ini mengikuti alur Borg and Gall (1989:783-795) dengan tahap research and information collecting (studi pendahuluan), planning (merencanakan penelitian), develop preliminary of product (pengembangan desain), preliminary field testing (uji coba lapangan 
awal), main product revision (revisi hasil uji lapangan terbatas).

Produk yang akan dikembangkan pada penelitian ini adalah bahan ajar matematika dengan Model Discovery Learning yang dibuat berdasarkan karakteristik siswa menengah ke bawah pada materi SPLDV kelas VIII SMPN 1 Seputih Agung untuk mengembangkan keterampilan berpikir kritis siswa.

Data keterampilan berpikir kritis diperoleh melalui tes. Sebelum tes diberikan maka soal di uji validitas, reliabilitas, tingkat kesukaran dan daya bedanya. Masing-masing diperoleh 5 soal yang dinyatakan valid dari 7 soal yang diujikan dan nilai reliabilitas tes 0,70 artinya tes reliabel atau ajeg dan dapat digunakan. Tingkat kesukaran soal nomor 1 dalam kategori mudah, sedangkan soal nomor 2 sampai dengan 5 dalam kategori sedang dan untuk nilai daya pembeda diperoleh soal nomor 1 sampai dengan nomor 5 termasuk dalam kategori baik, dan dilanjutkan dengan uji terbatas.

\section{HASIL DAN PEMBAHASAN}

\section{Validasi Bahan Ajar}

Produk yang dibuat berupa bahan ajar matematika dengan model Discovery Learning diuji melalui tahap formatif yang pertama, yaitu uji oleh diri sendiri. Selanjutnya uji ahli dan memperoleh persentase nilai sebesar 86,25\% dengan kategori sangat baik untuk validasi ahli materi, 84,09\% dengan kategori sangat baik untuk validasi ahli media, dan 91,6\% dengan kategori sangat baik untuk validasi ahli bahasa. Mengapa hasil validasi bahan ajar mendapatkan interpretasi sangat baik?, Hal ini dikarenakan dalam proses pembuatan bahan ajar dilakukan tahap demi tahap yang dilalui dengan baik, tahapan tahapan tersebut adalah:

\section{Studi Pendahuluan}

Berikut adalah beberapa hal yang menjadi perhatian dan temuan setelah mengadakan studi pendahuluan.

1. Peserta didik kelas VIII SMP yang berusia berkisar 14 tahun. Hal ini juga menjadi pertimbangan dalam menyusun bahan ajar untuk pembelajaran dengan Model Discovery Learning agar sesuai dengan karakteristik peserta didik. Materi pembelajaran ditemukan sendiri oleh peserta didik melalui bimbingan guru dan bahan ajar yang telah disusun dari hal hal yang konkrit menuju ke hal hal yang abstrak sesuai dengan usia mereka. Dengan perlakuan tersebut diharapkan dapat mempermudah proses pemahaman peserta didik terhadap materi pembelajaran.

2. Hasil studi literatur terhadap materi pembelajaran SPLDV berupa KI, KD dan Indikator pembelajaran yang 
dikembangkan berdasarkan acuan kurikulum 2013.

3. SMP Negeri 1 Seputih Agung telah menerapkan kurikulum 2013, dalam penerapan kurikulum tersebut peserta didik dan guru bidang studi matematika SMP Negeri 1 Seputih Agung menggunakan buku pegangan yang berupa buku cetak matematika konsep dan aplikasinya. Buku cetak tersebut hanya berisi materi singkat dan latihan soal, tidak terdapat kegiatan kegiatan yang berorientasi kepada peserta didik dalam proses pembelajarannya.

4. Selain menggunakan Buku cetak, guru bidang studi matematika SMP Negeri 1 Seputih Agung juga menggunakan buku pegangan guru yang diberikan pemerintah pada saat awal penerapan kurikulum 2013. Buku pegangan guru tersebut digunakan oleh guru bidang studi sebagai panduan dalam penerapan pembelajaran kurikulum 2013. Namun, dalam hal ini, guru masih kesulitan menggunakan buku pegangan guru dalam melaksanakan pembelajaran kurukulum 2013 di kelas sehingga banyak guru yang mencari bahan ajar yang tepat dalam menerapkan kurikulum 2013 dengan student oriented.

Penyusunan bahan ajar pembelajaran, terutama dari segi materi harus memudahkan peserta didik dalam memahaminya. Hampir seluruh peserta didik menyatakan buku pelajaran yang digunakan kurang menarik. Ketidakmenarikan buku pelajaran yang digunakan terletak pada kelengkapan, teknik penjelasan dan contoh aplikasi. Materi yang disajikan dalam bahan ajar harus sesuai dengan perkembangan kognitif peserta didik agar mudah untuk dipahami. Hal ini sesuai dengan Hanfiah dan Suhana (2012) yang mengungkapkan bahwa bahan ajar yang akan diberikan peserta didik perlu disesuaikan dengan tingkat perkembangan peserta didik.

Tujuan lain dari penyesuaian perkembangan peserta didik adalah untuk memudahkan peserta didik belajar secara mandiri. Hal ini sesuai dengan karakteristik bahan ajar yang diungkapkan oleh Depdiknas (2006) yang menyatakan bahwa sebuah bahan ajar dikatakan baik apabila bahan ajar tesebut disusun dengan menggunakan bahasa yang baik dan mudah dimengerti, disajikan secara menarik dilengkapi dengan gambar dan keterangan keterangan. Analisis kebutuhan guru perlu dilakukan supaya ada keselarasan antara kebutuhan peserta didik dan kebutuhan guru.

\section{Perencanaan Pengambangan}

Indikator hasil dari studi pendahuluan digunakan sebagai acuan dalam perencanaan pengembangkan materi pada bahan ajar yang meliputi penyajian materi, 
penyajian informasi, penyajian masalah, kegiatan percobaan dan latihan soal maupun evaluasi.

Dalam penyusunan materi Sistem Persamaan Linier Dua Variabel disiapkan pengumpulan informasi dari berbagai sumber rujukan baik dari buku tingkat universitas, buku matematika tingkat SMP, e-book maupun dari internet dan buku kurikulum 2013. Beberapa referensi tersebut kemudian dikemas untuk penyusunan materi bahan ajar SPLDV sesuai dengan kemampuan kognisi peserta didik. Baik dalam segi penyajian format, contoh soal, latihan soal, bahasa yang digunakan, ilustrasi yang menarik bagi peserta didik.

Penyusunan bahan ajar diawali dengan menyusun komponen Model Discovery Learning yang dalam bahan ajar. Komponen Model Discovery Learning yang diterapkan dalam bahan ajar adalah: Stimulation (Stimulasi/Pemberian Rangsangan), Problem Statement (Pernyataan/Identifikasi Masalah), Data Collection (Pengumpulan Data) Data Processing (Pengolahan Data), Verification (Pembuktian), Generalization (Menarik Kesimpulan/Generalisasi).

\section{Penyusunan Bahan Ajar}

Berikut adalah garis besar susunan bahan ajar Sistem Persamaan Linier Dua Variabel dengan Model Discovery Learning. a. Sampul luar berisi judul bahan ajar yang menggambarkan materi pokok yang dipelajari peserta didik dalam bahan ajar.

b. Bagian awal

1. Sampul dalam berisi identitas penulis, pembimbing, dan validator bahan ajar

2. Kata pengantar sebagai halaman pembuka yang menjelaskan peran bahan ajar dalam proses pembelajaran

3. Fitur bahan ajar yang menggambarkan komponen komponen bahan ajar dan kegiatan pembelajaran yang ada dalam bahan ajar.

4. Kompetensi inti, kompetensi dasar, indikator, tujuan pembelajaran, dan peta konsep pembelajaran.

5. Daftar isi yang memuat kerangka bahan ajar dan dilengkapi dengan nomor halaman.

c. Bagian Inti

1. Kegiatan pembelajaran yang dirinci dan disusun sesuai tahapan pembelajaran Model Discovery Learning

2. Kegiatan akhir yang berupa kesimpulan dari pokok bahasan.

d. Bagian akhir

1. Latihan ulangan yang berisi soal soal latihan dari semua pokok bahasan yang terdapat dalam bahan ajar. 
2. Daftar pustaka, berisi daftar rujukan yang digunakan untuk menyusun bahan ajar.

Perolehan kategori sangat baik untuk ketiga aspek yang dinilai tersebut juga disebabkan karena proses penyusunan bahan ajar dilakukan beberapa kali perbaikan berdasarkan saran dari masing masing ahli tentang isi bahan ajar yang baik, desain yang menarik serta kebahasaan yang lugas dan mudah dipahami siswa.

Berikut beberapa halaman yang direvisi berdasarkan saran dan masukan dari ahli.

\section{Ahli Materi}

Menambahkan masalah yang harus diselesaikan siswa di awal bab dan menambahkan soal yang mudah di-pahami peserta didik untuk men-jembatani peserta didik dalam mencapai soal yang lebih tinggi.

\section{Ahli Desain}

Memperbaiki cover bahan ajar dan memperbaiki desain page border bahan ajar dengan tampilan yang lebih menarik

\section{Ahli Bahasa}

Memperbaiki penulisan kalimat dengan memperhatikan subjek dan predikat, mengganti bahasa bahasa serapan dengan bahasa yang lugas dan menambahkan kata penghubung yang tepat antarkalimat dan antar paragraf.

\section{Keterampilan Berpikir Kritis}

Berdasarkan hasil pretest dan posttes dapat dilihat bahwa hasil perhitungan $\mathrm{N}$-gain menunjukkan nilai 0,58 dan dalam kategori sedang. Pada penelitian Yusmanto (2015) dan Ibrahim (2014) yang menerapkan Model Discovery Learning dalam perangkat pembelajarannya, mampu meningkatkan kemampuan berpikir kritis, dan didukung penelitian yang dilakukan oleh Astuti (2015) memberikan hasil bahwa data peningkatan keterampilan berpikir kritis peserta didik diperoleh melalui hasil pretest dan posttest, serta analisis peningkatan keterampilan berpikir kritis peserta didik setelah menggunakan bahan ajar dengan Discovery Learning menggunakan uji gain dan menunjukkan kriteria sedang.

Berdasarkan hasil analisis pada uji terbatas di kelas VIII G yang berjumlah 32 siswa diperoleh nilai posttest tertinggi yaitu 95 dan terendah yaitu 35 dengan rata-rata kelas yaitu 73,13. KKM yang digunakan pada kelas VIII adalah 75. Persentase kelulusannya yaitu $78 \%$. Hal ini berarti kelulusan yang diharapkan tercapai, yaitu lebih dari $75 \%$. Hal ini didukung oleh pendapat Sanjaya (2010:162) bahwa "ketuntasan belajar ideal untuk setiap indikator adalah dengan batas kriteria ideal minimum $75 \% "$. 
Bagaimana bahan ajar dengan

Model Discovery Learning dapat mengembangkan keterampilan berpikir kritis siswa? Berikut indikator keterampilan berpikir kritis yang dapat dikembangkan dengan bahan ajar dengan Model Discovery Learning.
1. Interpretasi

Dalam kegiatan ini peserta didik memasuki tahapan Stimulation dalam model pembelajaran Model Discovery Learning dimana peserta didik dapat menginterpretasikan masalah masalah yang mereka temui

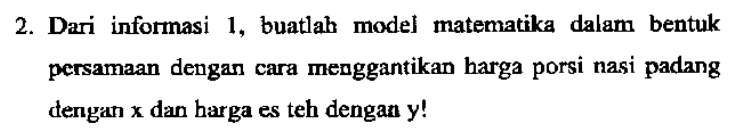

Gambar 1

Kegiatan Peserta Didik Tahap Stimulasi

dan akhirnya dapat mengkategorikan dan mempertimbangkan masalah masalah tersebut. Kemudian peserta didik mengolah, mengklasifikasikan dan bila perlu

\section{Analisis}

Dalam kegiatan ini peserta didik memasuki tahapan Problem Statement dalam Model Discovery Learning. Peserta didik mengidentifikasi sebanyak mungkin masalah yang relevan dengan bahan pelajaran, kemudian salah satunya dipilih dan dirumuskan dalam bentuk hipotesis (jawaban sementara atas pertanyaan masalah). Hal ini akan mengembangkan menghitung dengan cara tertentu serta ditafsirkan pada tingkat kepercayaan tertentu.

salah satu keterampilan berpikir kritis menurut Facione (Kowiyah, 2012) yaitu Analisis. Keterampilan analisis itu sendiri adalah keterampilan mengidentifikasi hubungan inferensial dan aktual diantara pertanyaan-pertanyaan, konsep-konsep, deskripsi untuk mengekspresikan kepercayaan, penilaian dan pengalaman, alasan, informasi, dan opini. 
Coba uraikan apa yang kamu ketahui dari diagram di atas dalam hal

Pen, mencari informasi yang dialami buk Retno, dan tuliskan pertanyaan

, Learning untuk Mengembangkan tentang apa yang ingin kamu ketahui mengenai diagram di atas! ilan Berpikir Kritis (Deni Efendi)

Selanjutnya dapatkah anda menguraikan apa yang dimaksud dari

penyelesaian persamaan linier dua variabel, tuliskan jawabanmu!

$2.500 \theta+1.50000=10.500$

$2.500 .3+1.500 .2=10.500$

Penyelesaian PLDV adalah berapa nilai variable $x$ dan $y$

sehingga kalimatnua menjadi benar.

Gambar 2

Kegiatan Peserta Didik Tahap Problem Statement

\section{Inference dan Eksplanasi}

5. Setelah membaca catatan diatas, kemudian tuliskanlah variable, koefisien variable $\mathrm{x}$, koefisien variable $\mathrm{y}$, dan konstanta dari persamaan yang telah kalian buat pada jawaban nomor 2 !

Variable $=x$ dan $y$

Korfisien $x=7$

Koefisien $y=7$

konstanta $=91.000$

\section{Gambar 3}

Kegiatan Peserta Didik Tahap Data Processing

Dalam kegiatan ini peserta didik memasuki tahapan data processing dalam Model Discovery Learning peserta didik mengolah data dan informasi yang telah diperoleh para peserta didik baik melalui wawancara, observasi, dan sebagainya, lalu ditafsirkan. Hal ini akan mengembangkan salah satu keterampilan berpikir kritis menurut Facione (Kowiyah, 2012), yaitu Inference. Keterampilan inference itu sendiri adalah keterampilan meng- identifikasi dan memperoleh unsur yang diperlukan untuk membuat simpulansimpulan yang masuk akal, membuat dugaan dan hipotesis, mempertimbangkan informasi yang relevan dan menyimpulkan konsekuensi dari data. Selanjutnya keterampilan eksplanasi merupakan keterampilan peserta didik dalam menyatakan hasil-hasil dari penalaran seseorang, menjustifikasi penalaran tersebut dari sisi konseptual, metodologis, dan kontekstual. 
4. Evaluasi

Dalam kegiatan ini peserta didik memasuki tahapan data collection dalam Model Discovery Learning. Peserta didik melakukan aktivitas menjaring informasi yang dibutuhkkan untuk menguji hipotesis yang diajukan.

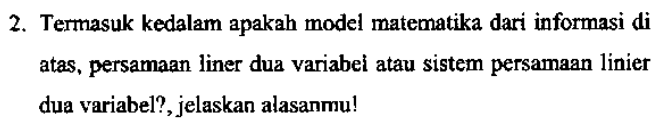

2. Termasuk kedalam apakah model matematika dari informasi di atas, persamaan liner dua variabei atau sistem persamaan linier dua variabel?, jelaskan alasanmu!

Sistem Persamaan Lnear Deva variable

Karena, lebih dari Satu per samaan

Gambar 4

Kegiatan Peserta Didik Tahap Data Collection

Hal ini akan mengembangkan salah satu keterampilan berpikir kritis menurut Facione (Kowiyah, 2012) yaitu Evaluasi. Dimana keterampilan eksplanasi itu sendiri

\section{Regulasi Diri}

Dalam kegiatan ini peserta didik memasuki tahapan Verification dan Generalization.Model Discovery Learning peserta didik melakukan pemeriksaan untuk membuktikan benar atau tidaknya hipotesis yang ditetapkan dengan temuan alternatif, dihubungkan dengan hasil data processing dan menarik sebuah kesimpulan dengan memperhatikan hasil verifikasi. Hal ini akan mengembangkan adalah keterampilan menyatakan hasilhasil dari penalaran seseorang, menjustifikasi penalaran tersebut dari sisi konseptual, metodologis dan kontekstual.

salah satu keterampilan berpikir kritis menurut Facione (Kowiyah, 2012), yaitu regulasi diri. Keterampilan regulasi diri itu sendiri adalah keterampilan secara sadar diri memantau kegiatan-kegiatan kognitif seseorang, unsur-unsur yang digunakan dalam hasil yang diperoleh, terutama dengan menerapkan kecakapan di dalam analisis dan evaluasi untuk penilaiannya sendiri. 


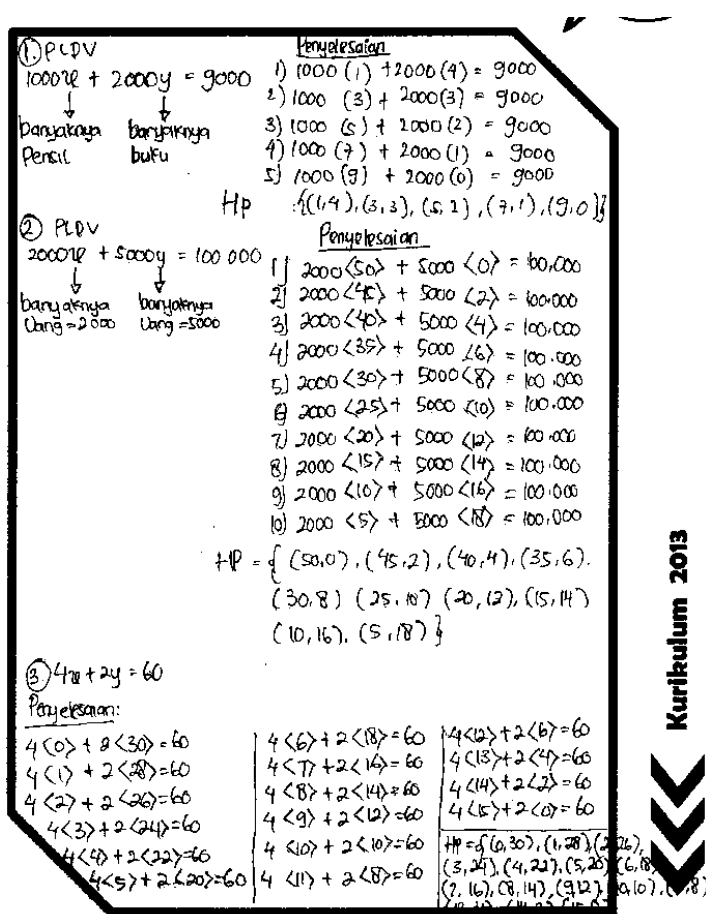

Gambar 5

Kegiatan Peserta Didik Tahap Verification Dan Generalization

\section{KESIMPULAN}

Berdasarkan hasil penelitian yang telah dilakukan maka dapat diambil kesimpulan bahwa; Hasil validasi bahan ajar matematika yang dikembangkan dengan Model Discovery Learning pada pokok bahasan SPLDV memperoleh interpretasi sangat baik. Hal tersebut diperoleh dari hasil penilain validator dengan rincian sebagai berikut. Ahli materi memberikan skor total 69 atau dengan persentase $86,23 \%$ sehingga termasuk dalam kategori sangat baik. Ahli desain memberikan skor total 74 atau dengan persentase $84,09 \%$ sehingga termasuk dalam kategori sangat baik. Ahli kebahasaan mem- berikan skor total 32 atau dengan persentase $91,6 \%$ sehingga termasuk dalam kategori sangat baik.

Selanjutnya hasil uji efektivitas terhadap penggunaan bahan ajar matematika dengan model Discovery Learning pada pokok bahasan SPLDV dalam meningkatkan keterampilan berpikir kritis siswa dinilai efektif. Hal tersebut dilihat dengan adanya peningkatan keterampilan berpikir kritis siswa setelah manggunakan bahan ajar matematika dengan Model Discovery Learning dengan perhitungan $\mathrm{N}$ gain sebesar 0,58. Peningkatan keterampilan berpikir kritis ini memiliki katergori sedang. Selain itu, tingkat ketuntasan hasil belajar juga melebihi persentase ketuntasan ideal, yaitu mencapai $78 \%$. 


\section{DAFTAR RUJUKAN}

Amri, S. dan Ahmadi, I. K. 2010. Kontruksi Pengembangan Pembelajaran. Jakarta: Prestasi Pustaka.

Astuti, Hany Yuliana.2015. Pengembangan Bahan Ajar Dengan Model Discovery Learning untuk Meningkatkan Kemampuan Berpikir Kritis Siswa SMA. Universitas Negeri Semarang [Online]. [http://lib.unnes.ac.id. Diakses 25 Maret 2018.]

Borg, W. R. dan Gall, M. D. 1989. Educational Research An Introduction. New York: Longman.

Cruickshank, Donald R. 2006. The Act Of Teaching, $4^{\text {th }}$ Edition. New York: Mc Grow Hill

Depdiknas. 2006. Kurikulum Tingkat Satuan Pendidikan. Jakarta: Depdiknas.

Hanafiah dan Suhana. 2012. Konsep Strategi Pembelajaran. Bandung: PT Rafika Aditama

Ibrahim, Rama Pratiwi.2014. Meningkatkan Kemempuan Berpikir Kritis Siswa Melalui Pembelajaran Matematika dengan Model Pembelajaran Discovery Learning pada Materi Trigonometri, Universitas Gorontalo [Online]. [http://eprints.ung.ac.id. Diakses 25 Maret 2018]

Kemendikbud. 2012. Survey Inter-national TIMSS. [Online]. [http://litbang.kemendikbud.go.id/index.php/survei-international-timss. Diakses 25 Maret 2018]

2014. Materi Pelatihanguru Implementasi Kurikulum 2013 Tahun 2014 SMP. Jakarta: Depdiknas

Kowiyah. 2012. Keterampilan BerPikir Kritis. Jurnal Pen-didikan Dasar Vol. 3, No.5. [Online].[http://id.portalgaruda.org. Diakses 25 Maret 2018]

Sanjaya, Wina. 2010. Strategi Pem-belajaran Berorientasi Standar Proses Pendidikan. Jakarta: Kencana

Schunk, Daleh H. 2012. Teori Teori Pembelajaran: Perspektif Pendidikan. Yogyakarta: Pustaka Pelajar.

Widodo,C. Dan Jasmadi. 2008. Buku Panduan Menyusun Bahan Ajar. Jakarta: PT Elek Media Komputindo

Yunarti, Tina. 2009. Pengajaran Berpikir Kritis. Prosiding Seminar Nasional Pembelajaran Matematika Sekolah, 6 Desember 2009 Jurusan Pendidikan Matematika UNY.

Yusmanto. 2015. Pengaruh Penerapan Model Pembelajaran Discovery Learning terhadap Peningkatan Kemampuan Berpikir Kritis Matematis dan Self Confidence Siswa Kelas $V$ SD. Bandung: UPI.[Online].[http://repository.upi.edu/19332/. Diakses 25 Maret 2018] 